\title{
SEARCHING FOR RENEWABLE ENERGY SOURCES ON URBAN AREAS
}

\author{
Lidiya Svirenko, \\ Yuriy Vergeles, \\ Olga Tugai \\ National Academy of Municipal Economy, Ukraine
}

\begin{abstract}
The possibilities and capacities of energy production from renewable sources in urban areas were studied on the example of the city of Kharkiv, Ukraine (population ca. $1.4 \mathrm{mln}$, occupied area ca. $320 \mathrm{~km}^{2}$ ). The following alternate renewable sources and ways for energy production (except solar and wind) have been identified: (1) biogas to be produced at municipal landfills; (2) biogas to be produced from sewage sludge accumulated at wastewater treatment plants; (3) wood wastes from urban dwellings' reconstruction and furniture renewal; (4) litter from tree stands of the city (woody and leaf litter, debris, dead wood, etc.); (5) biomass harvested while the phytotechnologies are applied for brown field remediation (energy crops, willows and poplars, etc.). The energy potential of primary and secondary renewable energy sources has been estimated. Approach to decision-making on optimal allocation of sites for decentralised energy production on the city's territory and relevant technologies for energy production are discussed.
\end{abstract}

\section{KEYWORDS}

Renewable energy sources, biogas, wood litter, urban areas, Ukraine

\section{INTRODUCTION}

Increasing demand for energy is a modern civilization's "trademark". In global and regional energy consumption cities take major part while global urban population is steadily growing. Increased demand and supply of energy is nowadays accompanied with drastically increased prices for energy from non-renewable sources and simultaneous depletion of such sources. Ensuring energy security and urban and regional development sustainability implies searching for both renewable sources and ways to improve energy efficiency $[3,6,9,15,18]$.

The European Union's energy policy targeted at increase of a share of total energy production in EU countries from renewable sources to $20 \%$ by year 2010 . The target will be achieved through introduction of the Intelligent Energy concept, supporting technological innovations and broad public campaigns ${ }^{1}$.

In the transition and developing countries whose economies are much dependent on exported energy sources national policies' development is generally taking similar direction although being less articulated. Ukraine is among such countries, and today its economy is based to the

\footnotetext{
${ }^{1}$ See: Sustainable Energy Europe Campaign. - http://www.sustenergy.org/tpl/
} 
great extend, on exported energy from non-renewable sources (oil and gas). Its own nonrenewable sources exploitation (oil, gas, black and brown coal) supplies only about $1 / 5$ of the total domestic demand, nuclear energy (also from exported nuclear fuel) provides for about half a total supply, and less than $2 \%$ of total energy is produced from alternate renewable sources. National Energy Strategy in middle and long terms foresees significant improvements of energy efficiency in all sectors of Ukraine's economy and better utilisation of energy from secondary and/or renewable sources [6]. However, practically very little progress was made in recent years to reach these objectives. Virtually, none of large cities and very few large industries introduced and implemented "intelligent energy" schemes, and the energy consumption, as well as waste generation continues to grow countrywide despite drastically increased prices for exported resources.

This paper aims to identify primary and secondary renewable energy sources in a typical large (post)-industrial city of Ukraine, Kharkiv, to estimate capacities and to show possible ways of utilisation of such sources in order to meet the objectives of National and Regional Energy Strategies in middle terms. However, in this study we do not address small hydropower, wind and solar energy, as well as heat pumps since that requires special investigation by specialists with relevant background. Mainly, we focus on organic wastes accumulated and collected and biomass produced in the city's area as potential sources of energy, since their contribution to overall energy supply of Ukrainian cities seems to be underestimated and their potential utilities are hence not exploited.

Recent developments in the field undertaken in different countries have shown remarkable capacities of municipal solid wastes as secondary energy sources. First, wood wastes generated from demolition and reconstruction of urban dwellings and furniture renewal, as well as residues from forest and wood processing industries located in cities may be either directly combusted or be used as a source of charcoal production $[5,8,19]$. Second, organic compounds of solid wastes and leaching products accumulated, stored and generated at municipal landfills can be transformed into biogas naturally or with application of physicalchemical and biotechnology methods $[7,10,12,13,14,17,22]$. The later ways combined with advanced cleaning of biogas provide for higher contents of methane, and a number of studies in European, Asian countries, Russia, Australia and USA proved feasibility of such way of waste utilisation to supplement energy generation in urban areas [7, 9, 10, 12, 17]. Among other components of biogas generated from solid organic wastes hydrogen can be mentioned that is also considered as one of future's fuels [20]. As for almost every big city waste utilisation and minimisation of landfill areas is an actual problem such direction as biogas production will get further attention and one can expect new developments towards improved efficiency of this process.

Another secondary renewable source of energy in urban areas is biogas obtained as a result of anaerobic digestion of sewage sludge. Several pilot to full-scale experiments and commercial implementations in this direction in Germany, Scandinavian and Baltic countries, Russia and Ukraine proved its feasibility $[12,13,16]$. Among recent developments resulted in improved efficiency of biogas-from-sludge production we can mention new technology of the Clausthaler Umwelttechnik Institut (CUTEC), Germany, that achieved 30\% increase in energy output ${ }^{2}$.

\footnotetext{
${ }^{2}$ See: CUTEC Report, 2004. /Otto Karlowitz, Managing Director. CUTEC Institut GmbH, Clausthaler, Lower Saxony, Germany.
} 
Biomass produced by an urban ecosystem has potential value as a primary renewable source of energy. This normally includes woody and leaf litter, debris, dead wood and timber from the urban forestry, and hay harvested from numerous urban lawns and road verges. By practices of Ukrainian municipalities such biomass is treated as an organic waste and, instead of energy production, it is directed to landfills during summer and autumn seasons every year. Not long ago it was even burnt in urban streets and yards in the open air, but nowadays such a practice is strictly prohibited by national sanitary regulations. In contrast to Ukraine and NIS countries, in many European cities technology schemes were adopted to utilise urban forestry litter and harvested biomass for the purposes of energy production. In Poland, a new EU Member state, there are more than 100000 boilers utilising energy from the burning wood biomass [18]. At the same time, a team from Ukrainian Research Institute of Technical Heat Physics (ITHP, Kyiv, Ukraine) developed the method and device for biomass processing, which allows obtaining solid fuel (charcoal) and combustible gas as final products. Charcoal can be further used for electricity production as well as for heat supply in steam-heating boiler [15]. Charcoal production is mentioned by British specialists as one of economic benefits of urban forestry [2]. An alternative way of biomass treatment is thermal decomposition and subsequent conversion of synthesised gas to liquid hydrocarbons. This technology of special bio-fuels production for future drive concepts using Fischer-Tropsch synthesis was developed at the already mentioned CUTEC-Institute $\mathrm{GmbH}$.

With increased application of phytoremediation systems to contaminated land rehabilitation in industrial and urban areas worldwide the biomass produced by such systems can also be harvested and utilised for the purposes of energy production by means of technological solutions as described above.

The last but not least to mention is a growing in recent years practice of energy crops (either annual or perennial herbaceous species) and energy wood plantations that may be introduced in urban or peri-urban areas. Brown fields and like lands suit such a purpose that a number of studies in the United Kingdom and Scandinavian countries, among others, confirmed [2, 11].

Although utilisation of the primary and secondary renewable energy sources in contemporary Ukraine is yet insufficiently understood and at the very preliminary stage, the urgent needs of national security in the energy field call for concrete practical actions. We made an attempt to show in this paper the prospects and opportunities for and possible benefits from incorporation of renewable energy sources that long have been associated with wastes only, on the example of the country's second largest city, Kharkiv. This study by no means provides for ready-to-use solutions and rather aims at raising awareness of municipal professionals, decision-makers and prospective investors to the problem outlined.

\section{MATERIALS AND METHODS}

\subsection{The city profile}

The city of Kharkiv founded in 1651-1654 grew from a small fortress, a frontier town to the second largest city in the nation, the biggest regional centre, and the former capital of Ukraine (19\&9-1934). It is located in the northeast part of country on rolling plain of the southeast fringe of the Forest-steppe zone of East Europe. Nowadays, Kharkiv is a central city for the region (Oblast) named after it. By the time of collapse of the Soviet Union the city of Kharkiv was a leading centre of education, research and technological development (especially in defence-related fields), culture, transportation with remarkable industries (machinery, aircraft, turbine, power, electric and transportation engineering). Decline of typical city of industrial 
era became a characteristic sign in Ukraine during the last 15 years, and the city of Kharkiv has not been an exception. Under conditions of transition economy the city's profile has significantly changed. After several years of strong economic decline some revitalization of industrial activities occurred in recent years, and the city's economy shows stable growth from 2001. However, at the same time its population decreased almost by $10 \%$ since 1990 when it reached its maximum, $1.6 \mathrm{mln}$. Recent census gave a figure of 1466300 inhabitants living in the city. Total city's area is ca. $320 \mathrm{~km}^{2}$, of which almost $210 \mathrm{~km}^{2}$ are built-up lands and about $140 \mathrm{~km}^{2}$ are occupied by urban forest [4]. About $3 / 4$ of total number of city's residents occupy multi-storied dwellings, and the rest inhabit private low-storied ones.

Total energy supply of the city of Knarkiv ranged $88450 \mathrm{GJ} /$ year (2003, [4]), of which $26 \%$ was supplied by a local thermal power station TEC-5, 16\% - by another local thermal power station, TEC-3, and the rest - by municipal heat generating company "Kharkiv Heating Networks". Main fuel used for centralized energy supply is methane gas extracted from the largest region's gas fields, "Shebelynske". Local energy strategy has been developed with relevance to national energy regulations, namely the Energy Efficiency Act of Ukraine (1994) and a number of presidential and governmental decrees (1994-2000). It is a part of a regional Integrated Programme of Energy Efficiency for 2003-2010 developed by Regional State Administration and approved by Regional Council. Energy efficiency goals are stated in annual plans and programmes of socio-economic development of the city of Kharkiv. Nevertheless, energy consumption and supply have increased by $23 \%$ since 2000 without significant improvement of energy efficiency.

\subsection{Case study areas}

In 2006-2007 we assessed the capacities of the urban area occupied by the city of Kharkiv in terms of primary and secondary renewable energy sources and their available stocks. Existing landfills and sewage sludge drying fields of the municipal wastewater treatment works were on the primary focus of field visits and information browsing. Biomass production potential was studied and assessed on the example of one of nine municipal districts - the Ordzhonikidzevski district on the city's southeast. The study areas are outlined on Figure 1. 


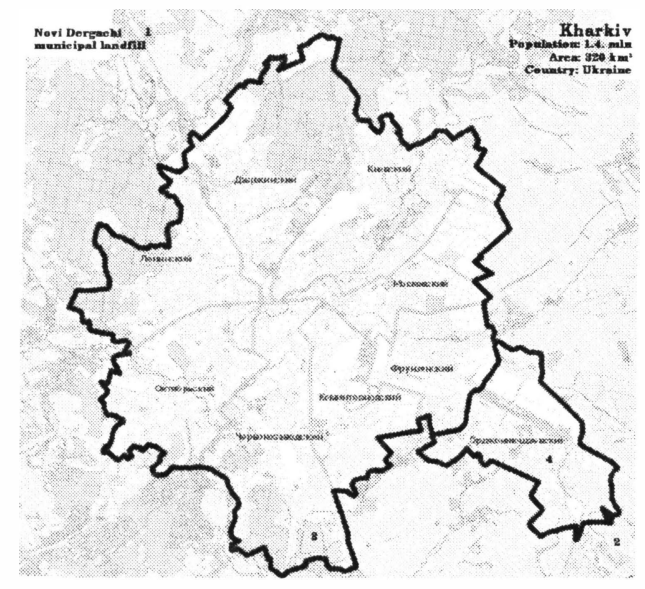

Figure 1. Study area: the city of Kharkiv, Ukraine: I - existing municipal landfill at the Novi Dergachi settlement; 2 - new private landfill nearby the Rohan residential area; 3 -sewage sludge drying fields of the municipal wastewater works; 4 - the Ordzhonikidzevski municipal district.

Municipal solid wastes are generated at $2325000 \mathrm{~m}^{3}$ per year and mainly accumulated at the municipal landfill nearby the settlement of Novi Dergachi, about $15 \mathrm{~km}$ to the north from the city. This landfill exploited for almost 10 years, is now overloaded containing $5.11 \mathrm{mln} \mathrm{m}$ of wastes and to be closed in the nearest years. An old landfill near the existing site has been closed over 10 years. However, the site selection and design for a new landfill are not yet adopted. Additionally to municipal landfills, a private landfill is located at the southeast city's fringe; by year 2006 it contained $5.5 \mathrm{mln} \mathrm{m}^{3}$ of wastes.

Sewage sludge generated at $1 \mathrm{mln} \mathrm{m}^{3}$ per year at two wastewater works of the Municipal Enterprise of Sewerage and Wastewater Treatment, "Kharkivkomunochystvod", is treated and stored at drying fields that occupy about 120 ha of lands in the southern part of the city, near the settlement of Bezlyudivka. With application of advanced mechanical treatment since 2005 , the sludge volume is significantly reduced as well as the area needed for sludge drying. In the future about 100 ha of existing fields will be reclaimed by the municipality, and application of phytoremediation measures is therefore expected. In our study, this area is considered for growing energy crops and woods.

The Ordzhonikidzevski municipal district (area $33.4 \mathrm{~km}^{2}$ ) with its industries and residential areas separated from the former with boulevards, greenways and parks served a good model area for estimation of amounts of biomass produced by the urban forestry and harvested on open public spaces. Today, tree stands occupy 936 ha, open public space -4 ha. Middle-aged trees (40-60 years) take the majority of total tree stands where Poplars (Populus deltoides, $P$. balsamifera, P. x berolinensis), Mapples (Acer negundo, A. platanoides), Lime-trees (Tilia cordata, T. $x$ europaea, T. platyphyllos), Ash (Fraxinus excelsior, $F$. lanceolata, $F$. americana) and Common Birch (Betula pendula) predominate. 


\subsection{Sources of information and methods}

For estimation of amount of biogas that may be obtained from city's landfills and data on solid wastes accumulation on the urban area, technical reports of the Research and Design Institutes of Municipal Engineering ("KharkivKomunNDIProject") and Advanced Technologies for Municipal Economy ("UkrKomunNDIProgres"), as well as annual reports (200 le2005) of the Kharkiv City Council were used.

Amount of biogas, which may be extracted from the landfill, was estimated as the following [7]:

$V_{B G}=M_{S W} \cdot C_{O M} \cdot(1-z) \cdot C_{a n \cdot d i g e s t}$

where $V_{B G}$ - amount of biogas, me ; $M_{S W}$ - total amount of solid wastes accumulated at a landfill, $\mathrm{kg} ; C_{O M}$ - content of easily digestible organic matter (normally equals $0.5-0 . \overline{\text { ) }}$; $z$ coefficient of ash content of organic matter (normally equals $0.2-0.3$ ); $C_{\text {an digest }}-$ degree of anaerobic digestion (normally equals $0.4-0.5$ ), $\mathrm{me}^{3} / \mathrm{kg}$.

Data on waste composition and, specifically, share of wood fractures in total amount of solid wastes were obtained from two monographs written by local professionals [1,9]. Total amount of wood wastes generated from the city's dwellings was estimated according to the Standards for solid waste accumulation in settlements of Ukraine ${ }^{3}$.

Information on energy value of sewage sludge was obtained from the Research and Development Division of the Municipal Enterprise of Sewerage and Wastewater Treatment, "Kharkivkomunochystvod".

Amount of biomass of urban tree litter and dead wood that may be annually harvested was estimated with the use of data from annual reports (2005-2006) of the Executive Committee of the Ordzhonikidzevski District's Council and following the Standards for solid waste accumulation in settlements of Ukraine and the Rules of Amenities and Utilities Planning in the City of Kharkiv ${ }^{4}$.

Rough estimation of biomass harvest from application of phytoremediation systems on contaminated and reclaimed urban lands was based on the published data from Scandinavia [11].

Specific energy and heating values for different materials were derived from the civil engineering reference books $[19,2$ le $]$.

\section{THE CASE STUDY: IDENTIFICATION AND ESTIMATION OF RENEWABLE ENERGY SOURCES IN THE CITY OF KHARKIV, UKRAINE}

\subsection{Municipal landfills as a source of biogas}

Following the data on actual amounts of municipal solid wastes accumulated and stored at two operated and one closed landfills and excluding wood wastes from the calculation the amount of potential biogas yield was estimated using formula ( $\notin$ ). We put the coefficient of

\footnotetext{
${ }^{3}$ The Order of the Ministry of Housing, Architectural Planning and Municipal Economy of Ukraine No. 7 of 10.01.2006. (in Ukrainian)

${ }^{4}$ Decision of the City Council of 10.05.2007. (in Ukrainian)
} 
biogas utilisation as $50 \%$, and, at the heating value of $20 \mathrm{MJ} / \mathrm{m}^{3}$ of biogas, we estimated total potential energy output from using this renewable secondary source in the city of Kharkiv (Table l).

Table 1. Estimated figures of volumes and potential energy output for biogas that may be produced from municipal solid wastes and leachate at landfills in the city of Kharkiv

\begin{tabular}{|c|c|c|c|}
\hline Landfill location & $\begin{array}{l}\text { Total waste } \\
\text { storage, } \mathrm{m}^{3} \text { (as } \\
\text { by 2006) }\end{array}$ & $\begin{array}{l}\text { Estimated yield of } \\
\text { biogas, } \mathrm{m}^{3}\end{array}$ & $\begin{array}{l}\text { Estimated energy } \\
\text { output, MJ, at } \\
50 \% \text {-utilisation of } \\
\text { biogas }\end{array}$ \\
\hline Dergachi (closed in 1998) & $N / A^{6}$ & $3.5-6.0 \cdot 10^{9}$ & $4.0 \cdot 10^{10}$ \\
\hline $\begin{array}{l}\text { Novi Dergachi, municipal } \\
\text { landfill }\end{array}$ & $5.11 \cdot 10^{6}$ & 1034775 & $1.035 \cdot 10^{7}$ \\
\hline Rohan, private landfill & $5.50 \cdot 10^{6}$ & 1113750 & $1.114 \cdot 10^{7}$ \\
\hline All operated landfills: & $10.61 \cdot 10^{6}$ & 2148525 & $2.149 \cdot 10^{7}$ \\
\hline
\end{tabular}

Comparing estimated potential energy output from landfill biogas that could be generated at 2 existing sites we found that it is compatible to $1 / 4$ of total annual energy consumption of the city. If we consider the annual rate of solid wastes accumulation in the city, and sound technology would be implemented to produce, collect and utilise biogas for energy production it would count to almost $5 \%$ of total annual urban energy supply.

\subsection{Municipal sewage sludge as a source of energy}

Recent measurements of heating value of sewage sludge from the treatment fields of the Municipal Enterprise of Sewerage and Wastewater Treatment, "Kharkivkomunochystvod", showed average figure of $21 \mathrm{MJ} / \mathrm{kg}$ of dried sludge with organic matter contents of $19 \%$. With annual generation of $1 \cdot 10^{6} \mathrm{~m}^{3}$, municipal sludge makes good potential secondary renewable energy source for the city. More detailed investigations on the technologies of its utilisation for the purpose of energy production and feasibility study are needed that will give correct estimation of this source's contribution to total urban energy supply in the future.

\subsection{Wood wastes}

The contents of wood and cardboard in all municipal solid wastes of the city of Kharkiv are $2.8 \%$ and $5 \%$ by volume, respectively. In large waste fractions contents of wood reach 66$75 \%$, and share of large fractions in total solid wastes is approximately $10 \%$ by volume [1]. We estimated total amount of solid wastes based on the Standards for solid waste accumulation in settlements of Ukraine as $0.15 \mathrm{~m}^{3}$ per year per person living in multi-storied residential houses, and $0.22 \mathrm{~m}^{3}$ per year per person living in low-storied dwellings. Taking total urban population at $1.4 \mathrm{mln}$ residents and assuming the ratio of residents of the former category to the later category as $3: 1$ we estimated amount of solid wastes generated at each kind of residential dwellings. Then, total mass of wood wastes was estimated at average wood density of $600 \mathrm{~kg} / \mathrm{m}^{3}$ (this index ranges from $550 \mathrm{~kg} / \mathrm{m}^{3}$ for pines and plywood to $800 \mathrm{~kg} / \mathrm{m}^{3}$

\footnotetext{
${ }^{5}$ Biogas yield estimation according to [ ]

"Data non-available
} 
for oaks [19]). For energy output estimations we used heating value of wood wastes as $19 \mathrm{MJ} / \mathrm{kg}$. The results are shown in Table 2.

Table 2. Total amount of annually generated wood wastes from residential areas of the city of Kharkiv and potential energy output from their utilisation

\begin{tabular}{|c|c|c|c|c|c|}
\hline $\begin{array}{l}\text { Residential } \\
\text { area } \\
\text { category }\end{array}$ & $\begin{array}{l}\text { Population, } \\
\text { mln. people }\end{array}$ & $\begin{array}{l}\text { Estimated } \\
\text { volume of } \\
\text { large } \\
\text { fractions of } \\
\text { solid wastes, } \\
\mathrm{m}^{3}\end{array}$ & $\begin{array}{l}\text { Estimated } \\
\text { volume of } \\
\text { wood wastes } \\
\text { (at } 66 \% \text { - } \\
\text { content), } \mathrm{m}^{3}\end{array}$ & $\begin{array}{l}\text { Estimated } \\
\text { wood waste } \\
\text { mass, } \mathrm{kg}\end{array}$ & $\begin{array}{l}\text { Estimated } \\
\text { energy value } \\
\text { of wood } \\
\text { wastes, MJ }\end{array}$ \\
\hline Multi-storied & 1.05 & 157500 & 103950 & $6.237 \cdot 10^{7}$ & $1.185 \cdot 10^{9}$ \\
\hline Low-storied & 0.35 & 77000 & 50820 & $3.050 \cdot 10^{7}$ & $0.579 \cdot 10^{9}$ \\
\hline City Total: & 1.40 & 234500 & 154770 & $9.287 \cdot 10^{7}$ & $1.864 \mathrm{e} 10^{9}$ \\
\hline
\end{tabular}

Even in case the wood waste would be utilised with an utilisation coefficient of 0.4 , this source of renewable energy would count up to $8 \%\left(0.7 \cdot 10^{9} \mathrm{MJ}\right)$ of total annual energy demand/supply of the city.

\subsection{Litter from urban tree stands}

Litter from tree stands of the model area consisted of:

- fallen and cut dead trees - 215 trees were removed in 2006;

- cut damaged trees and live trees removed for the purposes of infrastructure development and/or refurbishment - 200 trees in 2006;

- fallen leaves and tree branches.

Since removed trees were not valuated according the Forestry Regulations it was impossible to estimate even roughly the volume and biomass harvested from the former categories of tree waste. For the later category of litter, by the Standards for solid waste accumulation in settlements of Ukraine specific leaf fall accumulation value is suggested at $81 / \mathrm{m}^{2}$ of tree stands. Hence, for 976 ha of tree stands in the Ordzhonikidzevski municipal district total annual leaf fall was estimated as $78080 \mathrm{~m}^{3}$. With average density of dry fallen leaves at 10 $\mathrm{kg} / \mathrm{m}^{3}$ we got $7.8 \cdot 10^{6} \mathrm{~kg}$ of leaf biomass. Usually only a half of leaf litter is removed out tree plots in average (from $100 \%$ on streets and boulevards to only $5-10 \%$ in dense forest-like stands), so biomass available for further utilisation is about $4.0 \cdot 10^{6} \mathrm{~kg}$. Multiplying by 10 we got a rough estimate of total available urban leaf litter. Further utilisation of this primary renewable source - either for composting or biogas/energy production purposes - will be justified as a result of feasibility study of relevant technologies introduction to the municipal economy. At the moment we could suggest that this source of energy would count only for $1.0-1.5 \%$ of total energy demand/supply of the city.

In addition to tree wastes in the model area, small amount of harvested biomass came from mowing the lawns at open public spaces ( $4 \mathrm{ha}$ ) and from removal of almost 42000 annually planted flowers at the end of vegetation season. For the later, harvested biomass was estimated as $8.4 \cdot 10^{3} \mathrm{~kg}$. 


\subsection{Biomass produced with applied phytoremediation systems}

Although phytoremediation measures were not yet applied in the city of Kharkiv at the scale larger than $0 . d$ ha, these are seen as a prospective source of biomass for additional alternate energy production. In the nearest years in the future phytoremediation systems may be applied at the existing municipal sewage sludge drying fields on the area of 100 ha. We recommend that 60 ha of this area to be planted with energy willow and poplar plantations with a short rotation period of 3 years, when average shout height reaches $4-6 \mathrm{~m}$. Then every year a $1 / 3$ of the planted area, i.e. 20 ha, might be harvested and replanted with new shouts. From published data [11], dry biomass is estimated as 10-15 t/ha, totally 200-300 t per year. Its utilisation might result in almost $3.6-5.4 \cdot 10^{6} \mathrm{MJ}$ of energy annually from one relatively small plot.

\section{CONCLUSIONS}

Our preliminary study found that in the city of Kharkiv there is a plenty of still unused primary and secondary renewable energy sources:

- solid wastes and landfill leachate rich of organic matter;

- municipal sewage sludge;

- large fractions of wood wastes that should be treated separately from total municipal solid wastes;

- urban tree and leaf litter;

- biomass of herbaceous plants harvested from open public spaces (lawns, road verges, etc.).

Rough estimation of total energy output that could be obtained at simultaneous utilisation of biogas and biomass gave a figure of $15-20 \%$ of total annual energy supply in the city of Kharkiv from these renewable energy sources only. In present, however, these sources are not utilised at all, and further investigations on technology efficiency and feasibility of biogas, energy and other possible benefits production, as well as on logistics of biomass collection points and small heating plants/facilities location are needed. It is certainly a decentralised solution to urban energy supply that complements existing centralised system. However, questions of what could be capacities of single facilities utilising different sources of renewable energy in the city, where should these be located, how many customers these would serve, and what are environmental impacts of such facilities still need to be addressed. A pilot scale application in the nearest future would provide for the information upon which decisions on full-scale implementation of technologies and facilities for renewable energy production and utilisation in the city of Kharkiv will be made.

As concluding remarks, we can add that in 2005 the National Academy of Sciences together with the Ministry of Energy of Ukraine have presented the Strategy of Renewable Energy Sources Development in Ukraine until the year 2030 that complemented the National Energy Strategy. It pointed out that in 2001 renewable energy sources in Ukraine totaled 5.54 mlnd of conditional fuel (tcf), of which only $0.99 \mathrm{mln}$ tcf related to what is called bio-energy. Prospects for 2010 are that total renewable energy sources in the country will count for 6.99 $\mathrm{mln}$ tcf with a share of bio-energy at $1.66 \mathrm{mln}$ tcf. For 2020 relevant figures are prospected as 14.34 and 6.3 , and for 2030 - as 21.6 and $10.83 \mathrm{mln}$ tcfe[6]. So both total output and the share of energy from biomass and biotechnological treatment of solid wastes and sludge are prospected to increase remarkably, and this makes a good challenge for the city of Kharkiv, in 
particular, in strengthening energy security through technology and organizational innovations.

\section{ACKNOWLEDGEMENTS}

The authors kindly appreciate the information and intellectual support for this study given by Ms Kateryna V. Abashyna (R\&D Institute "KharkivkomunNDIProject"), Dr Yuriy L. Kovalenko (Kharkiv City Council) and Mr Dmytro V. Zhukov (Executive Committee of the Ordzonikidzevski Municipal District's Council). Special thanks are to the Scientific Committee of the Eco-Tech Kalmar'07 Conference for their intention to publish this paper.

\section{REFERENCES}

[1] Babaev, V. N., Korin'ko, I. V., Shutenko, L. N., eds., 2004. Polimernye otkhody v kommunal'nom khozyaystve goroda (Polymer Wastes in Municipal Economy). National Academy of Municipal Economy, Kharkiv (in Russian).

[2] Bradshaw, A., Hunt, B., Walmsley, T., eds., 1995. Trees in the Urban Landscape: Principles and Practice. E. \& F.N. Spon, London.

[3] Chekalin, V., Liubarskaya, M., 2005. The role of solid waste management system in increase of security by power resources. In: Proceedings of Kalmar ECO-TECH'05: Waste to energy, bioremediation and leachate treatment, November 28-30, 2005, pp. 47-53.

[4] Chmykhalo, M. L., Mamontova, O. G., 2004. Kharkiv: Statystychnyy zbirnyk do 350richchya (Kharkiv: A 350-Anniversary's Statistical Reference Book). Regional Statistics Authority, Kharkiv (in Ukrainian)

[5] Claesson, T., Sarenbo, S., Mellbo, P., Stålnacke, O., 2005. Nutrient recycling by using residues from forest industry. In: Proceedings of Kalmar ECO-TECH'05: Waste to energy, bioremediation and leachate treatment, November 28-30, 2005, pp. 55-61.

[6] Geletucha, G., Kudrya, S., 2005. Ukrayina: netradytsiyni ta vidnovlyuvani dzherela energiyi (Ukraine: Non-traditional and renewable energy sources). Zelena energetyka (Green Energy), No.2 (18), 2005.pp. 8-10. (in Ukranian)

[7] Gurvich, V. I., Lifshitz, A. B., 2001.Dobycha i utilizatsiya svalochnogo gaza (Landfill Gas Output and Utilization). Moscow (in Russian).

[8] Horttanainen, M., Luoranen, M., Eriksson, N., 2005.The future of local waste material utilization in distributed energy production in Finland. In: Proceedings of Kalmar ECOTECH'05: Waste to energy, bioremediation and leachate treatment, November 28-30, 2005, pp. 73-82.

[9] Kasimov, A. M., Semenov, V. T., Kovalenko, A. M., Aleksandrov, A. M., 2006. Tverdye bytovye otkhody: tekhnologii, oborudovaniye, problemy i resheniya (Solid Municipal Wastes: Technologies and Facilities, Problems and Solutions). National Academy of Municipal Economy, Kharkiv (in Russian).

[10] Komatsu, T., Inaba, R., Furuichi, T., Nishi, N., Tanikawa, N., 2005. Study on recovery of biogas from mixed biowaste for regional biogasification system. In: Proceedings of Kalmar ECO-TECH'05: Waste to energy, bioremediation and leachate treatment, November 2830, 2005, pp. 89-98.

[11] Lundström, I., Hasselgnen, K., 2003. Uptake of metals in willow biomass plantations fertilised with sewage sludge. In: Proceedings of Kalmar ECO-TECH'03: Bioremediation and Leachate Treatment, November 25 - 27, 2003, Kalmar, Sweden, pp. 79-91.

[12] Mata-Alvarez, J., ed., 2001. Biomethanization of the Organic Fraction of Municipal Solid Wastes. IWA Publ., London. 
[13] Mežapuḳe, K., Bendere, R., Zariṇa, Dz., Dubova, L., 2005. Biowaste recycling technologies in Latvia. In: Proceedings of Kalmar ECO-TECH'05: Waste to energy, bioremediation and leachate treatment, November 28-30, 2005, pp. 105-112.

[14] Niskanen, A., Lappalainen, S., Horttanainen, M., 2005.Utilization of landfill gas in emission trading from the Finnish viewpoint. In: Proceedings of Kalmar ECO-TECH'05: Waste to energy, bioremediation and leachate treatment, November 28-30, 2005, pp. 115123.

[15] Nosach, W., 2007. Vmesto nefti i gaza - biomassa (Instead of oil and gas - biomass). Zerkalo Nedeli (Weekly Mirror) Newspaper, No.34 (663), September 15 (in Russian).

[16] Plyaskina N. I., 2007.Othody stochnykh vod goroda kak vozobnovlyaemyy istochnik energii: ekologicheskaya i economicheskaya effektivnost' (Sewage sludge as a renewable energy source: Environmental and economic efficiency). In: Sbornik dokladov: Pyatyy mezhdunarodnyy kongress po upravleniyu otkhodami i prirodookhrannym tekhnologiyam WasteTech-2007, 29 maya - 1 iyunya 2007, Moskva, Rossiya (Proceedings of the 5th International Congress on waste management and environmental technologies WasteTech2007, May 29 - June 1, 2007, Moscow, Russia), pp. 302-303. (in Russian)

[17] Sanphoti, N., Towprayoon, S., Chaiprasert, P., Nopharatana, A., 2006. The effects of leachate recirculation with supplemental water addition on methan production and waste decomposition in a stimulated tropical landfill. J. Envir. Management, 82(1), 77-82.

[18] Shmidt G., 2004. Vidnovlyuvana energetyka novykh chleniv ES (Renewable energy in new EU Members). Zelena energetyka (Green Energy), No.2 (14), 2004, p.4-7. (in Ukrainian).

[19] Sjöblom, R., Tham, G., Haglund, J.-E., Sjöö, C., 2005.Environmental qualification of ash from wood-based recycled fuels for landfills. In: Proceedings of Kalmar ECO-TECH'05: Waste to energy, bioremediation and leachate treatment, November 28-30, 2005, pp. 135144.

[19] Staroverov, I. G., ed., 1967. Spravochnik proyektorivshchika promyshlennykh, zhilykh i obshchestvennykh zdaniy i sooruzheniy. Ch. 1. (Designer's Handbook: Industrial, Residential and Communal Buildings and Constructions. Pt. 1). Stroyizdat, Moscow (in Russian).

[20] Vaidyanathan, A., Mulholland, J., Ryu, J., Smith, M. S., Circeo, L. J., Jr., 2007. Characterization of fuel gas products from the treatment of solid waste streams with a plasma arc torch.J. Envir. Management, 82(1), 77-82.

[21] Yakovlev, V.F., ed., 1994. Inzhenernoye oborudovaniye zdaniy i sooruzheniy: Entsiklopediya (Engineering Equipment of Buildings and Constructions: Encyclopedia). Stroyizdat, Moscow (in Russian)

[22] Yelistratov, V., Maslikov, V., Ioksha E., 2007. Obosnovanie energeticheskogo ispolzovaniya biogaza na poligone tverdykh bytovykh otkhodov v regione g. SanktPeterburg (Backgrounds for biogas utilization to energy at the solid waste landfill in the region of Saint-Petersburg) In: Sbornik dokladov: Pyatyy mezhdunarodnyy kongress po upravleniyu otkhodami i prirodookhrannym tekhnologiyam WasteTech-2007, 29 maya - 1 iyunya 2007, Moskva, Rossiya (Proceedings of the 5th International Congress on waste management and environmental technologies WasteTech-2007, May 29 - June 1, 2007, Moscow, Russia), p. 300. (in Russian)

[23] Yudkevich, Yu., Korshikov V., 2004. Vugillya z derevnykh vidkhodiv (Charcoal - from wood wastes). Zelena energetyka (Green Energy), No.2 (14), 2004, p. 22. (in Ukrainian). 